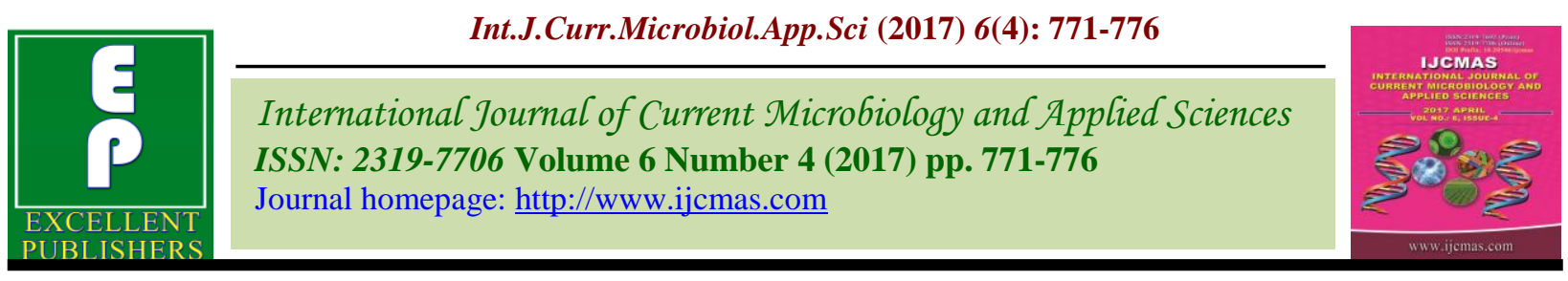

Original Research Article https://doi.org/10.20546/ijcmas.2017.604.096

\title{
Studies on Molecular Characterization of Salmonella spp. Isolated from Field Samples of Small Ruminants
}

\author{
B.N. Paramesh*, A. Basavaraj, S.J. Arun and R. Bhoyar \\ Department of Veterinary Microbiology, Veterinary College, Bidar, India \\ *Corresponding author
}

A B S T R A C T

Keywords

Salmonella, Small ruminants, Isolation, DNA isolation and PCR.

Article Info

Accepted:

06 March 2017

Available Online:

10 April 2017
Molecular characterization of the Salmonella spp isolated from small ruminants in and around Bidar. A total of 140 fecal samples collected were from sheep and goats. Based on the morphological, cultural and biochemical characterization indicated that 8 isolates were Salomnella spp. Biochemically confirmed isolates were subjected to invA gene based PCR and diagnostic amplicon specific to virulence gene of $284 \mathrm{bp}$ was evident in all the 8 Salmonella isolates indicating potential carriage of invasion properties linked to virulence.

\section{Introduction}

Salmonellae are one of the most common causes implicated in outbreaks of food born infectious disease around the world (AbouZeed et al., 2000). Salmonellae have a wide host range, including, animals, birds and human (Douce et al., 1991). Salmonellae produce a variety of putative virulence determinants, including adhesions, invasion, fimbriae, exotoxin and endotoxin (Jones et al., 1982). Virulence of microorganism is associated with the capacity to attach and colonize at the site of infection, with subsequent damage to the host and is promoted by aggregation that interferes with the host defense (Abou-zeed et al., 2000 and Pasquaii et al., 2004). The isolation and identification of Salmonellae by traditional methods is time consuming and laborious.
The polymerase chain reaction (PCR) provides a way of overcoming these difficulties and allows amplification of the target DNA (Murugkar et al., 2003). The aim of this study was to determine virulence patterns of Salmonella spp isolated from sheep and goats. All isolates were tested for presence of virulence invA gene.

\section{Materials and Methods}

Isolation and identification of Salmonellae

A total of 140 fecal samples from sheep and goats were collected. The collected samples were added to the pre-enrichment media (Selenite F broth and Tetrathionate broth) 
and were incubated at $37^{\circ} \mathrm{C}$ for 24 hours. The suspected colonies cultivated onto MacConkey's agar, XLD agar, Salmonella Shigella agar and BGA. The inoculated plates were incubated for 2448 hours at $37^{\circ} \mathrm{C}$. Suspected colonies were identified primarily as Gram- negative rods. The pure colonies of the isolates were identified biochemically using Sugar fermentation Reaction (Karim et al., 2008).

\section{Detection of Salmonella spp by PCR}

\section{Isolation of DNA}

The DNA was extracted from the isolated colony by Snap-chill method (Zaheri et al., 2005) and isolated DNA was subjected to PCR by using reported Salmonella specific primers (invA gene).

Determination of purity and yield of the DNA samples by UV spectrophotometry

The purity and concentration of the extracted genomic DNA was estimated by UV spectrophotometry. An aliquot of $20 \mu \mathrm{l}$ of DNA sample was dissolved in $0.98 \mathrm{ml}$ of sterile distilled water. The diluted DNA was transferred in to $1 \mathrm{ml}$ microcuvette and the optical density (OD) was read at $260 \mathrm{~nm}$ and $280 \mathrm{~nm}$ in a UV spectrophotometer. Sterile DW was used as blank. The ratio of 260/280 OD was calculated. A ratio of 1.7 to 1.9 was considered pure. Further, the purity of the DNA sample was checked by electrophoresis on $(0.8 \%)$ agarose gel.

\section{The following primers were used}

Two oligonucleotide primers were selected for Salmonella

Fowared: [5'-GTG AAA TTA TCG CCA CGT TCG GGC AA-3']
Reverase: [5'-TCA TCG CAC CGT CAA AGG AAC C-3']

\section{PCR amplification and cycling protocol}

DNA samples were amplified in a total of $50 \mu 1$ of the following reaction mixture (Table 1). After mixing the contents, tubes were centrifuged to collect the contents in the bottom. The tubes with cap were placed firmly into the thermal cycler and conditions were set as detailed below (Table 2).

\section{Electrophoresis}

The PCR products were visualized by gelelectrophoresis. Samples of final PCR product were mixed with loading dye and loaded onto a 1.5\% agarose gel and subjected to electrophoresis for 1 hour at two V. in LX TBE buffer (Murugkar et al., 2003).

\section{Results and Discussion}

All suspected colonies of Salmonella on the basis of cultural and morphological properties were subjected to biochemical tests (Table 3). Eight isolates were confirmed to be Salmonella species after the biochemical results.

\section{PCR based confirmation of Salmonella to genus level}

The PCR is a highly accurate method which makes it possible to detect nucleic acid amplification products. The results can be obtained rapidly so that they can be used not only to support bacteriological investigation but also to make the result more reliable (Galan and Curtiss, 1991). 
In the present study, a PCR was used to amplify Salmonella specific target DNA sequences. A new set of oligonucleotides primer taken from the invA gene was used for amplification to detect and identify Salmonella serovares. The primers are different from those suggested in previous studies of (Baumler et al., 1997). The investigation using PCR for the presence of invA gene in this study demonstrated its presence in all examined Salmonella isolates. This finding was consistent with previous reports (Galan and Curtiss, 1991) that established the presence of $i n v A$ gene in nearly all Salmonella spp.

Table.1 Components of PCR reaction mixture

\begin{tabular}{|l|l|l|}
\hline Sl. & Components & Volume per \\
No. & & reaction \\
\hline 1 & PCR master mix (Taq buffer,Taq polymerase,dNTPs) & $25 \mu \mathrm{l}$ \\
\hline 2 & Primer Forward & $2 \mu \mathrm{l}$ \\
\hline 3 & Primer Reverse & $2 \mu \mathrm{l}$ \\
\hline 4 & Template (Salmonella DNA) & $2 \mu \mathrm{l}$ \\
\hline 5 & Nuclease free water -to make a final volume of $50 \mu \mathrm{l}$ & $19 \mu \mathrm{l}$ \\
\hline & \multicolumn{2}{|c|}{ Total } \\
\hline
\end{tabular}

Table.2 PCR program for amplification of invA gene

\begin{tabular}{|l|l|l|c|c|c|}
\hline \multicolumn{2}{|l|}{ Step } & Temperature & Duration & Cycle \\
\hline 1 & \multicolumn{2}{|l|}{ Initial denaturation } & 95 & $1 \mathrm{~min}$ & 1 \\
\hline \multirow{3}{*}{2} & \multirow{3}{*}{ Cycling } & Denaturation & 94 & $1 \mathrm{~min}$ & 35 \\
\cline { 3 - 5 } & & Annealing & 55 & $1 \mathrm{~min}$ & \multirow{2}{*}{} \\
\cline { 3 - 5 } & & Extension & 72 & $1 \mathrm{~min}$ & \multirow{2}{*}{1} \\
\hline 3 & & Final denaturation & 72 & 5 min & \\
\hline
\end{tabular}


Table.3 Summary of the biochemical test results of Salmonella isolates

\begin{tabular}{|l|l|l|l|l|l|l|l|l|l|}
\hline Sl. No. & Biochemical test & G1 & G2 & G3 & G4 & G5 & G6 & G7 & G8 \\
\hline $\mathbf{1}$ & Indole formation & - & - & - & - & - & - & - & - \\
\hline $\mathbf{2}$ & Methyl red test & + & + & + & + & + & + & + & + \\
\hline $\mathbf{3}$ & $\begin{array}{l}\text { Voges-Proskauer } \\
\text { Reaction }\end{array}$ & - & - & - & - & - & - & - & - \\
\hline $\mathbf{4}$ & Citrate utilization & + & + & + & + & + & + & + & + \\
\hline $\mathbf{5}$ & Urea hydrolysis & - & - & - & - & - & - & - & - \\
\hline $\mathbf{6}$ & TSI H2S production & + & + & + & + & + & + & + & + \\
\hline $\mathbf{7}$ & Catalase & + & + & + & + & + & + & + & + \\
\hline
\end{tabular}

(+) Positive after 48hrs of incubation

(G) Isolates Salmonella

Plate.1 PCR amplification of inv-A gene of Salmonella isolates; M- 100 bp DNA ladder; Lane 1- Positive control; Lane- 2,3,4- Salmonella isolates; Lane 5- Negative control

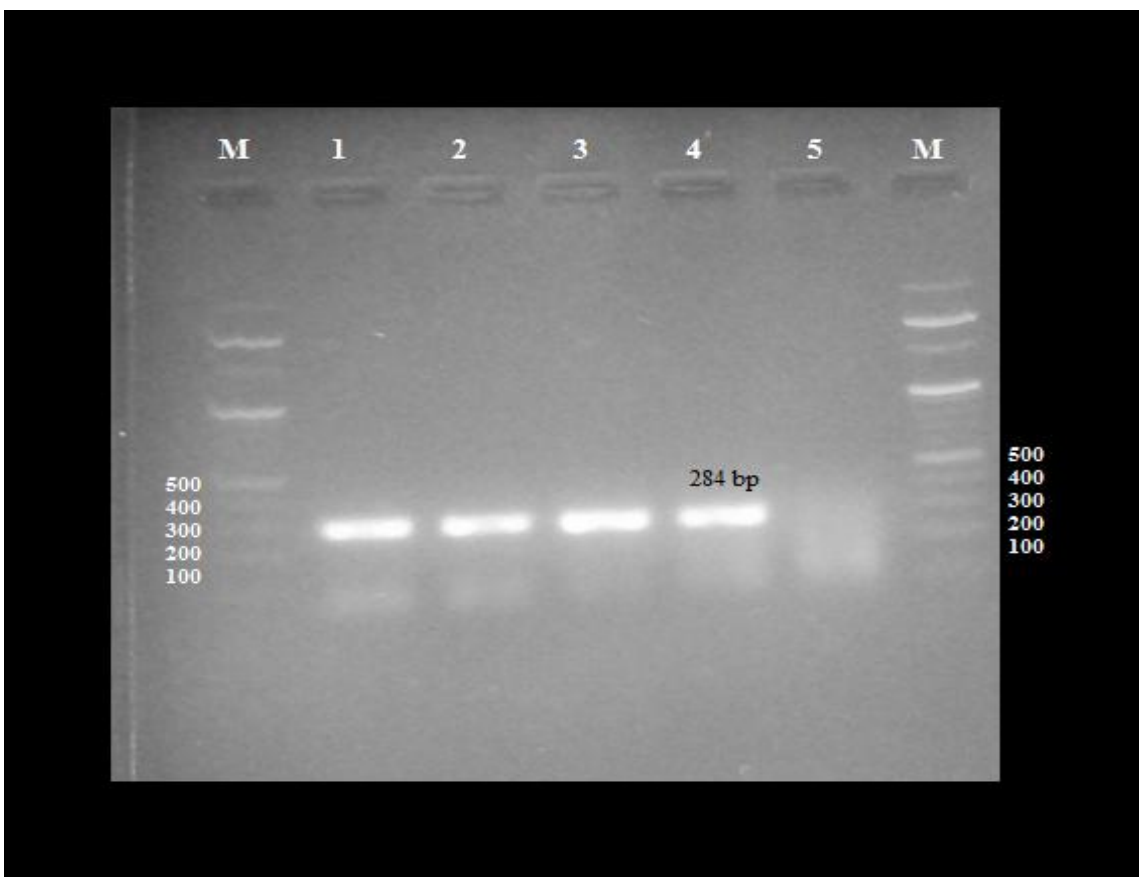


Plate.2 PCR amplification of inv-A gene of Salmonella isolates; M- 50 bp DNA ladder; Lane 5,6,7,8- Salmonella isolates

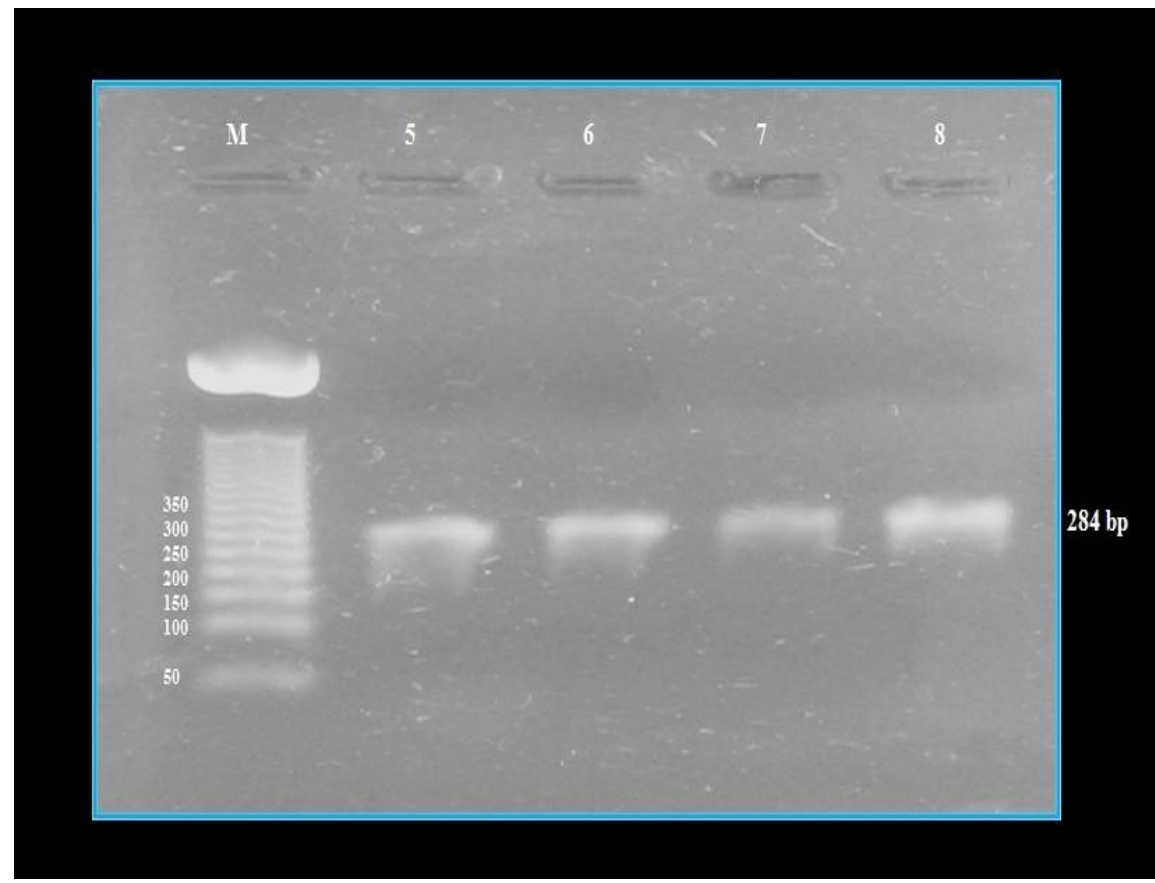

The invA gene is important in the invasion of phagocytic epithelial cells and entry into the intestinal mucosa (Tanaka et al., 2004). Based on the high specificity of primers targeting invA gene, they were employed for the specific confirmation of the Salmonella isolates.

All the Salmonella suspected cultures subjected to PCR amplification generated a product of approximate molecular size 284 bp. 50 and 100 bp DNA marker was used as a molecular weight marker. The band size detected in all the Salmonella isolates and analyzed by agarose gel electrophoresis 8 isolates were confirmed to genus level by invA gene based PCR (Plate 1 and 2).

From the present studies it was concluded that Salmonella is highly pathogenic microorganism affected animal production and cause serious diseases. The virulence effects of Salmonella attributed to its abilities to adherence and attachment to the host epithelial cells, also the presence of invA gene which responsible for the invasion properties.

\section{Acknowledgement}

Authors are thankful for Department of Veterinary Microbiology, Veterinary college Bidar. Karnataka Veterinary Animal Fisheries science University Bidar, Karnataka (India).

\section{References}

Abouzeed, Y.M., Hariharan, H., Poppes, C. and Kibenge, F.S.D. 2000. Characterization of Salmonella isolates from beef cattle broiler and human sources on princes Edward Island. Comp. Immun. Micro. and Infect. Dis., 23: 253 - 266.

Baumler, A.J., Tsolis, R.M., Valentine, P.J., Ficitt, T.A. and Heffron, F. 1997. Synergistic effect of mutation in 
invA and IPFC on the ability of Salmonella typhimuriurn to cause murine typhoid. Infect. Immun., 65(7): 2254-2259.

Douce, G., Amin. And Strphen, J. 1991. Invasion of HEP2 cells by strains of S.typhimurium of different virulence in relation to gastroenteritis. $\mathrm{J}$. Med. Microbiol., 3: 349-257.

Galan, J.E. and Curtiss, R. 1991. Distribution of the Inv A-B-C-D genes of Salmonella typhimurium among other Salmonella serovars mutants of Salmonella typhi are deficient for entry into mammalian cells. Infect. Immunol., 59: 2901-08.

Jones, G.W., Rabert, D. KD. Svirarich, and Whitlield, H.J. 1982. Association of adhesive,invasive, and virulent phenotypes of Salmonella typhimurium with autonomous 60megadalton plasmids. Infect. Immun., 3: 476-486.

Karim, M.R., Khan, M.S.R., Kayesh, M.E.H., Islam, M.R. and Gani, M.O. 2008. Isolation and characterization of sheep salmonellae in and around Bangladesh Agricultural University Campus. Bangl. J. Vet. Med., 6(1): 7578

Murugkar, H.V., Rahman, H. and Dutta, P.K. 2003. Distribution of virulence genes in Salmonella serovars isolated from man and animals. Ind. J. Med. Res., 117: 66 -70.

Pasaquaii, A., Ferriese, L.G. and Almeda, T.S. 2004. Serotype and virulence factors of Salmonella interotoxogenic strains. J. Clin. Microbiol., 39(12): 4500-4505.

Tanaka, K., Nishimori, K., T. and Yokomizo, Y. 2004. Molecular characterization of Salmonella enterica serotype Typhimurium. J. Clin. Microbiol., 42(4): 1807-1812.

Zaheri, S.T., Mahzounish, M. and Saeedzadeh. 2005. The isolation of antibiotic resistant Salmonella from intestine and liver of poultry in Shiraz province of Iran. Int. J. Poult. Sci., 4(5): 320-322.

\section{How to cite this article:}

Paramesh, B.N., A. Basavaraj, S.J. Arun and Bhoyar, R. 2017. Studies on Molecular Characterization of Salmonella spp. Isolated from Field Samples of Small Ruminants. Int.J.Curr.Microbiol.App.Sci. 6(4): 771-776. doi: https://doi.org/10.20546/ijcmas.2017.604.096 